TURIZAM

Volume 22, Issue 2

52-62 (2018)

ORIGINAL

SCIENTIFIC PAPER

\title{
Environmental and Social Responsibility Supplemented with Green Case Studies from the Side of the Tourism Service Providers
}

\author{
Andrea Horváth ${ }^{\mathrm{A}}$, Mónika Jónás-Berki ${ }^{\mathrm{A}}$ \\ Received: January 2018 | Accepted: March 2018 \\ DOI: $10.5937 / 22-17527$
}

\begin{abstract}
The environmental and social responsibility is a less researched area of tourism operators in Hungary. The tourism sector is one of the least regulated economic sectors in the global economy, but it can be seriously affected by ecological and social systems. The tourism supply requires a large amount of resources; therefore, a significant amount of waste is generated. By recognizing the effects of tourism, it is crucial for every society and economy to move forward to a more sustainable approach. At the social level, it can generate core processes, contribute to the population decrease in the area, but it can also cause social conflicts. The environmental and social sustainability requires a comprehensive approach and intervention to the sector as a whole. A wide range of stakeholders should be involved at all levels in order to create sustainability. The aim of the research is to explore the issue of environmental sustainability among tour operators by using Hungarian case studies.
\end{abstract}

Keywords: sustainability, responsible tourism, hospitality, Hungary

\section{Introduction}

Nowadays, tourism is a decisive economic sector. By retrospecting to the last few decades, both the growth of international and national tourism can be recognised which can significantly contribute to GDP in certain countries. The total contribution of tourism to the world GDP was 10.2\%, meanwhile in Hungary 10.5\% in 2016 (WTTC, 2017). However, the increment of the growth, as at all economic sectors, means several negative and positive effects. The research intends to emphasise the issue of responsibility that plays an important role by preventing the unfavourable effects. Our work focuses on the micro level, due to the fact that the tourism service providers are the real actors who are able to take actions locally and can create sustainable destinations. The paper would not like to focus on taking a position in connection

A University of Pécs, Faculty of Natural Sciences, Doctoral School of Earth Sciences, 2Faculty of Natural Sciences, Institute of Geography, Department of Tourism, Ifjúság Str. 6., HU - 7624 Pécs, Hungary

* Corresponding author: androsz@gamma.ttk.pte.hu 
with the debate of responsibility that has been existing in literature for a long time ago; from the point of view that what sort of business behaviour it counts.

\section{Theoretical background}

Several national and international researchers have been dealing with the effects of tourism (Lengyel, 2004; Dávid, (ed.) 2012; Puczkó, Rátz, 2002; Ritchie, Crouch, 2003; Petrić, 2003; Lanza et al., 2005; Page, 2007; Michalkó, 2004, 2012). Although they focus on the research question, but essentially the same conclusions can be deducted from their papers. Tourism has a great impact on the socio-cultural, economic and physical background of the destination.

Basically, the following statement should be agreed:

'...Tourism inherently is not dangerous to its environment, only if forms spontaneously, develops unsystematically and at an unchecked way. The reduction or the elimination of the negative effects and the strengthening of the positive ones - ultimately the creation of sustainable tourism - can be achieved only through conscious developments.' (Lengyel, 2004 p. 245). This conscious development is served by numerous development strategies at different levels. Ideally the implementation of actors is indispensable to the creation process, because the efficiency of the top-down defined and directed purposes are ambiguous, if they do not fit into the locality, namely the notions of the host destinations. Related to the conscious planning and development, two declarations of the specialised organisation of the United Nations, World Tourism Organisation (WTO) can be stated, accepted at highlighted events: 1980 Manila, World Conference on Tourism and 1989 Hague, Inter-Parliamentary Conference on Tourism, where it was stated that apart from the economic aspects; social, environmental and ethical viewpoints also have to be taken into consideration. Moreover, they secured the necessity of the cooperation of state and private sector at the planning process and emphasised the importance of tourism resources.

At the Conference on Environment and Development of the United Nations in 1992 in Rio de Janeiro, the action plans of the document called 'AGENDA 21' declared comprehensive sustainable aims. The tourism sector has already realised its great responsibility, but the development of the sector also depends on to what extend it endeavours to effectively and sustainably utilise its resources, as it basically serves their existence. After a few years, the WTO (World Tourism Organisation), the WTTC (World Travel and Tourism Council) and the Earth Council created the document called 'Agenda 21 for the Travel and Tourism Industry: Towards Environmental Sustainable Development in 1996'. The document contains the basic principles of sustainability, it draws priorities and tasks by emphasizing the partnership among governmental and professional bodies, tourism offices and companies for the practical implementation and efficiency (Puczkó, Rátz, 2002; AGENDA 21 for the Travel \& Tourism Industry Towards Environmentally Sustainable Development 1996).

The Global Code of Ethics for Tourism established in Santiago (Chile) in 1999 (UNWTO, 2001), describes tourism as the factor of sustainable development. Furthermore, the environmental and social responsibility of tourism policy is also mentioned in the articles.

'Sustainable tourism means: economically viable, but does not destroy the resources on which the future of tourism will depend, notably the physical environment, and the social fabric of the host community' (Swarbrooke, 1999).

As Swarbrooke (1999) also remarks, sustainable tourism is in a close relationship with several types of tourism that are often improperly used as synonyms. All of the enumerated terms 


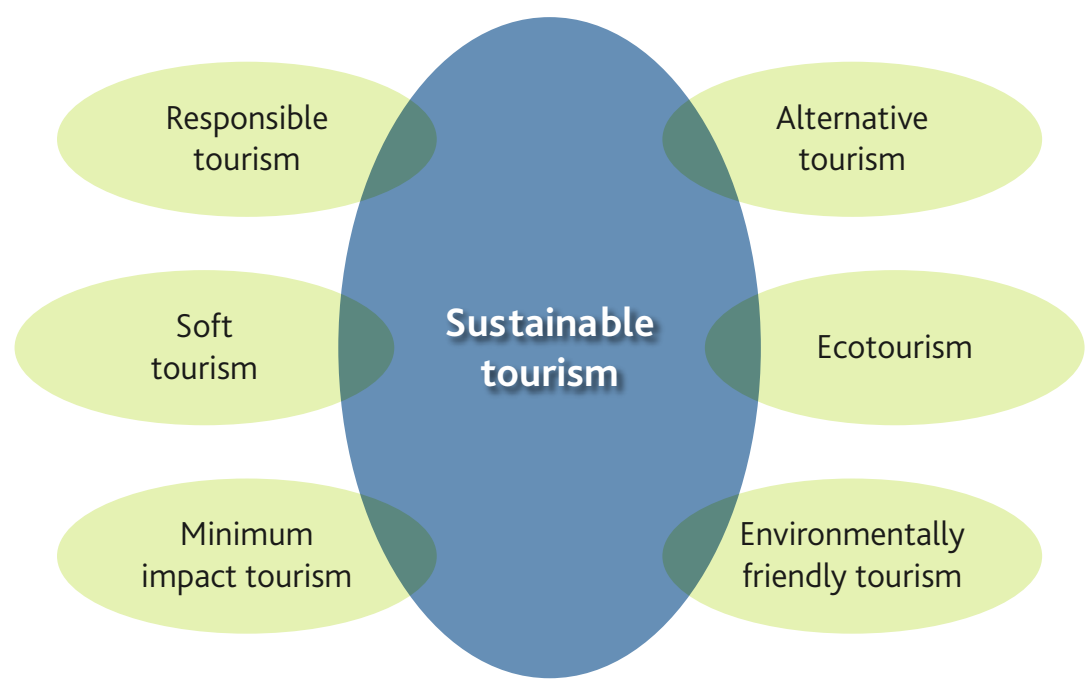

Figure 1. The relationship among sustainable tourism and other terms Source: Swarbrooke, 1999 p. 14

of Figure 1 indicate sustainable tourism; however, it cannot be pronounced that we can speak about sustainable tourism for example through utilising eco-friendly materials (furniture, textiles).

At present days, the eco-friendly products and services are not completely unknown for the nowadays self-conscious consumers. The appearance of this approach can be dated back to the 1980 s and 1990 o among the tourists, when the so-called archetype of the 'green tourist' generated a tourism demand. However, we can find several examples for bio-, eco- and environment-friendly labelled products or services for the purpose of marketing, which are far away from them. In case of tourism companies and firms, it is a frequent phenomenon to use selective waste management stocks in order to maintain the pretence of the eco-friendly outlook.

\section{Responsible tourism}

Responsible tourism is less-known in Hungary. It is largely due to the fact that it can be considered similar to sustainable tourism; moreover, the definition itself is also unclear. This paper takes into consideration the following definition of the Cape Town Declaration on Responsible Tourism (2002): Responsible tourism is tourism which:

- minimizes negative social, economic and environmental impacts

- generates greater economic benefits for local people and enhances the well-being of host communities

- improves working conditions and access to the industry

- involves local people in decisions that affect their lives and life chances

- makes positive contributions to the conservation of natural and cultural heritage embracing diversity

- provides more enjoyable experiences for tourists through more meaningful connections with local people, and a greater understanding of local cultural, social and environmental issues

- provides access for physically challenged people 
- is culturally sensitive, encourages respect between tourists and hosts, and builds local pride and confidence'

According to the above, a much simpler picture is outlined, regarding the actions. Similarity can be found with sustainable tourism, which is not a coincidence. It is not that there is a need to a brand new attitude, merely from the participants of sustainable tourism both at the side of demand and supply a proactively is needed.

The green or eco-friendly innovations and the application of innovative technologies in the tourism industry have been increasingly spreading. Regarding the hotel industry, besides the initial expenditure requirements there are no differences between hotel chains and independent ones (Gyurácz-Németh, 2014). As in case of a private household the energy efficiency is a cost reducing factor, like among the tourism service providers. This kind of investment can seem to be evident, because it can make the business more profitable, however, the lack of financial capital can mean an obstacle.

Unsystematic or massive tourism can evoke negative attitude or even sometimes aggression at the host destination. Recently a series of pictures spread all over the world because of the media, according to which the local citizens of big cities were rebelling, among others against the large number of tourists, against the shiftless settlements, against the degradation of their micro-environment and against the more frequent confrontations. After Dubrovnik and Venice, there were demonstrations in Barcelona in Spain and in San Diego, as well. The so called anti-tourist campaigns are the results of a certain level of conflicts that crossed the threshold of the tolerance of the local society (theguardian.com). It obviously indicates that the actors of the tourism sector have to undertake a much more significant role from social point of view. The definition of CSR (Corporate Social Responsibility) is known and utilised for other participants in economic life; moreover, it shifts into the value driven management which is far beyond the former one. However, it does not refer to the fact that the tourism service providers do not emphasise the ethical behaviour.

Environmental and Nature Conservation Inspectorate, based on the preliminary inquiry, made a decision about classification of accommodation facilities. If it is bound to environmental impact assessment activity by the classification into facilities, the Government Regulation (314/2005. (XII. 25)) ensures the audit of environmental effects in case of such an investment and prescribes the environmental licensing or the permit for environmental protection. However, the tourism service providers have to take into account the social and cultural effects of tourism. A favourable relationship with the stakeholders can optimise or strengthen the market role of the certain service provider.

According to the environmental responsibility and sustainability, several international programmes were born (e.g. the Planet 21 Programme), which also takes place in tourism. The tourism accommodation providers reacted to the approach, so the International Hotels Environment Initiative (IHEI), now known as the International Tourism Partnership (ITP) was funded. The International Tourism Partnership brings together the leading international hotel companies of the world to provide a platform for social and environmental responsibility within the sector. Among its members several brands can be found, such as the InterContinental Hotels Group, Four Seasons Hotels and Resorts, Hyatt, Kempinski, Fairmont Hotels and Resorts (Figure 2) (ihei.org).

Nevertheless, social responsibility seems to be much harder to adapt. According to the global trends, several big hotel chains, for example the Accor Hotels, the RadissonBlu, utilise a charter, so it is part of their business policy. In theory, responsibility is mediated by the man- 


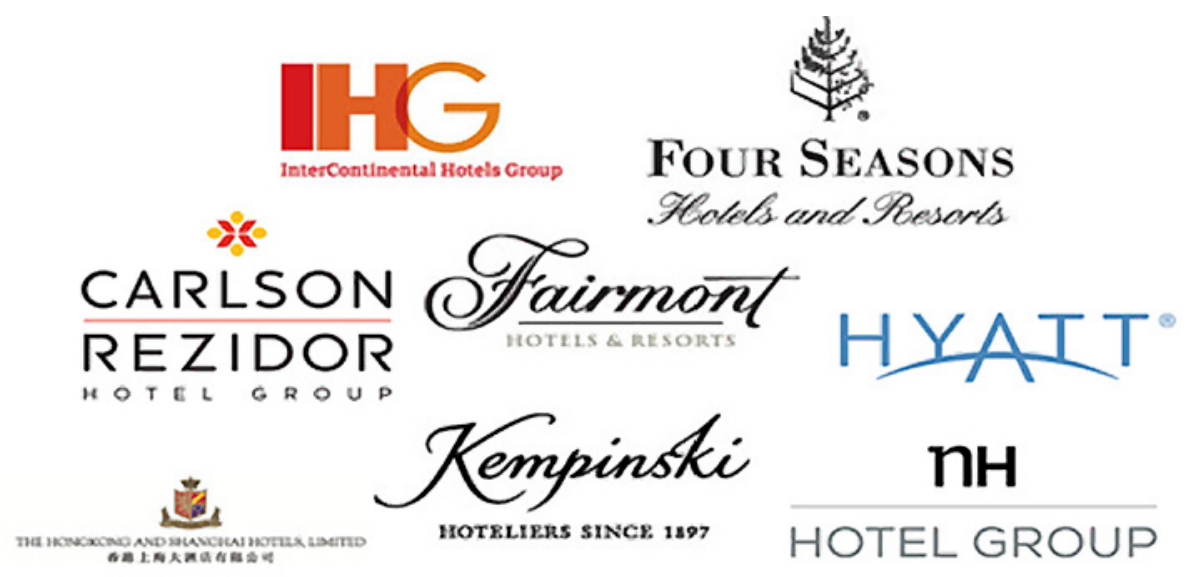

Figure 2. The members of IHEI

Source: http://www.ihei.org/

agement, concerns the workers (education), the local society (economy); as well as the information of the guests. Such a behaviour is desirable at the global market, demands the increase of the competitiveness and complex approach. Unfortunately, the picture seems to be less idyllic, if only the superficial half-measures are part of a marketing trick and the aim is to merely attract more and more guests. (Due to these types of applications CSR became ethically controversial and can be questioned in the business life.).

\section{Environmental awareness in tourism in Hungary}

Environmental awareness in tourism in Hungary is in its initial phase, yet. Due to the tenders and projects and in some cases the commitments of the proprietors of the hotels, it can be seen among the leading hotels of the market.

The hotel and catering industry, especially the sector of hotels can undertake a pioneering role in connection with the environmentally conscious and responsible developments and operations at the tourism market. This is the sector in which appropriate amount of capital and knowledge become concentrated around the issues of sustainability and environmental awareness; yet incentive tools and project subsidies are the ones that support the new technologies here, as well.

Social responsibility is only in an initial phase. Obviously, it is part of the business policy at the Hungarian units of the international hotel chains. The adaptation and use of international 'best practises' have paved the way for the spread of social responsibility and engagement. There is a lack not only of knowledge or 'best practises' to be followed, but the commitment is also missing. Those entrepreneurs who battle for operating their enterprise more profitably, hardly identify with their social responsibility, although their economic role would expect it.

\section{The Green Hotel Award}

The Association of Hungarian Hotels and Restaurants first announced the tender for the 'Green Hotel Award' in 1993, more than 20 years ago, in order to create an environmentally responsible thinking. The number of the owners of the award has been increasing since the middle of 
the 2000 (Table 1 ) which is probably due to the availability of the project findings for tourism development investments.

Table 1. The winners of 'Green Hotel' award from the beginning

\begin{tabular}{|l|c|c|c|c|c|c|c|c|c|c|c|}
\hline Territory & 1995 & 1997 & 1999 & 2001 & $\mathbf{2 0 0 3}$ & $\mathbf{2 0 0 5}$ & $\mathbf{2 0 0 7}$ & $\mathbf{2 0 0 9}$ & $\mathbf{2 0 1 1}$ & $\mathbf{2 0 1 3 / 1 4}$ & $\mathbf{2 0 1 5 / 1 6}$ \\
\hline Budapest & 3 & 3 & 12 & 15 & 13 & 14 & 21 & 21 & 19 & 11 & 20 \\
\hline Hungary without Budapest & - & - & 5 & 5 & 2 & 8 & 9 & 14 & 18 & 9 & 17 \\
\hline All & 3 & 3 & 17 & 20 & 15 & 22 & 30 & 35 & 37 & 20 & 37 \\
\hline Hotel chains and independent hotels \\
\hline Hotel chain & 3 & 2 & 9 & 10 & 7 & 10 & 21 & 26 & 28 & 12 & 26 \\
\hline Independent/private & - & 1 & 8 & 10 & 8 & 12 & 9 & 9 & 9 & 8 & 11 \\
\hline
\end{tabular}

Source: Albert Tóth, 2016

This tender concentrates on those fields within hotel management which are important in connection with energy efficiency. However, from the point of view of environment awareness fundamental principles are ascertained as conditions, which should be evident during the management. For example, only that unit can apply for a project which implements and complies with the environmental legislation concerning the hotel, over and above the hotel will send the annual declaration to the authority by the deadline. A question besides the basic criteria in accordance with the environmental legislation is whether environmental policy or carbon footprint count. Apart from the calculation of the carbon footprint, further criteria include such simple methods as the selective waste collection and the use of the grease trap. All of these elements are the conditions of applying for a project. In order to win the award of 'Green Hotel of 2017-2018', the applicant has to collect 70 points out of 135, as a basic criterion, from which $60 \%$ is based on the responses to the $32+28$ questions.

As the part of the project, apart from the above-mentioned calculation of the carbon footprint, a questionnaire should be answered divided into eight themes and their authenticity should be confirmed by real documents (e.g. minutes, invoices). The topics of the questions are the following: information, energy, water, sewage, waste management, ozone layer protection, green purchasing and green office. The winners of the award are entitled to hold the emblem of 'Green Hotel' that can definitely improve the image of the hotel; moreover, it can target the environmentally conscious segment with its marketing methods.

\section{Research methods}

The evaluation of the secondary data literature (studies and reports) is inevitable in order to make the issue of responsibility comparatively well-defined among tourism service providers.

On the basis of the secondary data, collected from the webpage and the regulation of the Association of Hungarian Hotels and Restaurants, the territorial dispersion of the accommodations holding the award of 'Green Hotel' was investigated with cartography methods of QGIS 2.18 programme. The primary research includes semi-structured and unstructured interviews, whereby qualitative information was acquired. By choosing the proper case studies, we also took into consideration in which regions there is a gap at the distribution of 'Green Hotels'. That is why we chose three four-star accommodations in the South Transdanubian region that have already done preliminary steps towards environmental or social responsibil- 
ity on the basis of preliminary webpage analysis. The interviewees were the head of the hotel management of CROCUS Gere Wine Hotel and Wine Spa, Villány (Ferenc Schmidt); and the head of the hotel management of Fordan Hotel, Pécs (Bíborka Horváth).

\section{Results}

The title of 'Green Hotel 2017-2018' could be applied for in 2016. According to the data from the webpage and the regulations of the Association of Hungarian Hotels and Restaurants (MSZÉSZ), a North - South territorial division outlines with the supremacy of Budapest of the holders of the award (Figure 3).

\section{"Green Hotels" spatial distribution in Hungary} (by capacity and category)

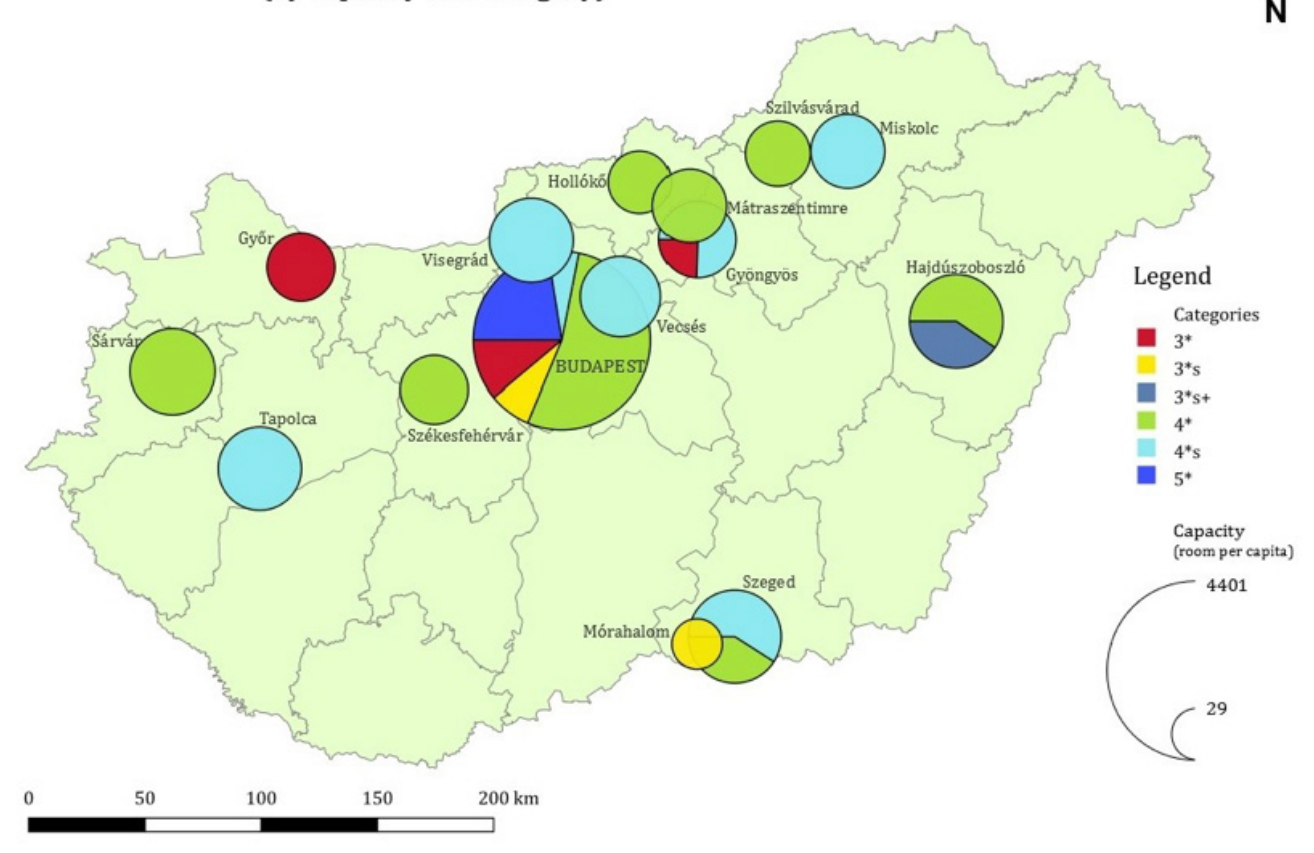

Figure 3. The distribution of hotels holding the title of 'Green Hotels 2017-2018' Source: Dobre, Horváth, 2017

The capital is the most dominant by both concerning the number of the rooms and the categorical classification of the hotels. Two hotels in the South Great Plain (Csongrád county) are the only exceptions. On the basis of the data of the Central Statistical Office, 1072 hotels can be found without the wellness ones, from which only 41 units got the award of 'Green Hotel'. It is only $4 \%$. 


\section{Case study 1: The CROCUS Gere Wine Hotel Resort \& Wine Spa}

The viticulture of the Villány Wine Region has 1000 years old tradition. The red wine of Villány is now acknowledged not only in Hungary but also internationally.

The four-star CROCUS Gere Wine Hotel is located in the heart of Villány, and it has altogether 34 rooms. In 2017 they won the Award of Excellence of booking.com with 9.5 points; nevertheless, the hotel received the highest acknowledgement of TripAdvisor, the 'Award of the Travellers' Choice' for the third time in 2017. In 2015 they got into the TOP 25 in the same category, and in 2016 the travellers put the hotel among the most popular ones.

The slogan of the family owned hotel - 'the complex Gere wine experience; taste, feel, experience...' - can be characterised by quality without compromise. It used to be a guest house, but nowadays the four-star hotel with a restaurant, a wine-wellness department also offers a special selection of services noted in Hungary.

'The main idea in fact offers a set of services, which are based on its own products, providing a complete solution for wine and gastronomy at top quality for tourist desiring for rural accommodation.' (Kovács, Schmidt, 2015).

The expectation of the proprietors is to highlight the grape and wine culture everywhere. It is not only because of the internationally famous wine region and of the first Hungarian wine route, but also due to fact that the family has been the owner of a winery and dealing with grape- and wine production since 1991. They are producers of well-known quality wines.

They advocate sustainable tourism at a pro-active way as a tourism accommodation and catering provider. Among others, they pursue the use of renewable energy resources with an environmental conscious attitude and with the use of innovative technologies. Furthermore, they also make efforts to utilise the waste created during grape production by heating the furnace with prunings. The further plans include the application of a composting machine - as a first tourism service provider in Hungary - in order to recycle the organic waste. Currently the waste is collected selectively, however they believe that the decrease of the amount of organic waste by composting processes is a much more efficient and environment friendly solution.

The hotel has a 40 square meter swimming pool and the water is provided by their own well. At the department of Wellness and Spa, the cosmetics for the beauty and vino therapy treatments are provided by the Gere Attila Winery, and are all from certified organic farms in Villány. The treatment of the CROCUS VINO THERAPY utilises grape and wine-based cosmetics, manufactured by their own formulae. According to the knowledge of the authors, there is no other national complex sale based on wine culture.

On the basis of the interview, they have much more difficult tasks in connection with social responsibility. The hotel employs altogether 58 people, which number is relatively high in this sector, however, the issue of labour shortage also affects their management; so only a few temporary employees are employed. Therefore, their main aim is to avoid fluctuation and keep the permanent members of the staff, to preserve the current situation of human capital. There is an agreement between the proprietors and the manager of the hotel, according to which the satisfaction of the employees does not only cover the financial background, but they also have to know their expectations. An anonymous stress factor research is carried out within their HR, from which valuable information is gained in the aspect of different departments, supervisors or even the whole hotel. They also regard as natural the provision of different games (XBOX, darts) at the resting rooms for the staff. With the aim of team-building they regularly organise and take part in common programmes at external places, which, according to the experiences so far strengthen the common cooperation and the loyalty to the hotel, as well. 
Transportation is an impedimental factor from the point of view of labour, especially because most of the staff are from the neighbouring settlements (Siklós, Bóly, Pécs). Unfortunately, commuting by public transport is rather difficult. As the proprietors of the hotel cannot change this factor, apart from having a staff room, they even bought a house next to the hotel in order to convert it to an independent staff house.

Mandula ('Almond') Restaurant and Wine Bar accompanies with the wine hotel. In the restaurant it is a challenge to find and purchase excellent quality ingredients. The main concept is to put wine into the focus, compared to the previous ones. The menu is designed by the chef and matched to the wine (e.g. the degustation menu), also associated with seasonality, so they use ingredients according to the certain season. Therefore, the local farmers are preferred, supporting thereby the local economy.

Their further future aims include to apply for the Green Hotel Award, as this award is thought to be in accordance with the values and profile of the hotel.

\section{Case study 2: The Fordan Hotel}

The Fordan Hotel opened in 2010 and is situated in the heart of Pécs on the borderline of the historical city. The three-star accommodation has 31 rooms altogether.

The owner is engaged in environmental issues, who was driven by environmental awareness, therefore more than $200,240 \mathrm{oW}$ solar panels were settled on the roof of the hotel, co-financed by European Union grants in 2011. The electricity supply of the hotel is covered by the solar panels seen on the top of the building.

The company forms its business strategy by taking into consideration the principles of sustainable development. As part of this strategy and viewpoint, the first electric car charger was built in Pécs at the car park.

The Blue Economy Summer School is organised every year in Pécs, led by Günther Pauli and with the participation of several experts of the research field. Besides the fact that the Fordan Hotel is one of the conference venues and also serves as an accommodation for the participants of the event, moreover, the proprietor of the hotel is also a participant member of this summer school. The accommodation is attached to the summer school at several points, for example some newly invented sustainability ideas are just put into practise at the hotel, such as the aquaponic system.

Apart from the solar panels and the e-charger there are no other energy awareness programmes and approaches in the marketing system of the hotel. According to the opinion of the manager of the hotel, those tourists who are interested in this attitude typically book a night at four- and five-star hotels. However, the emphasis in the marketing strategy has been relocated to MICE tourism since January 2017, so it advertises itself as a business hotel. A slow increase can be seen, after the exploitation of annual $45 \%$ in 2016.

The catering of the guests is ensured by the directly connected Fordan Centre Billiards and Restaurant, which is one of the units of the catering industry (MEVID Ltd.). There were also some attempts for the consumption of local products, but it did not seem to be profitable. However, it must be highlighted that because of the administration in food industry, the verification of the origin of the certain product does not allow the procurement of local food ingredients or homemade products for the meals of the guests. 


\section{Conclusions}

On the basis of the case studies examined, neither professional calling nor responsible attitude can be questioned, but it is also evident that neither is enough if they do not reach at least the management level. Whereas it can be seen at CROCUS Gere Wine Hotel that not only the owners but also management and employees have a proactive attitude to the issue and are proud of the innovative solutions applied, at Fordan Hotel this does not reach beyond the level of the management and even the investments realised so far are not considered relevant for the improvement of the image of the hotel.

The first steps towards environmental awareness are already visible in Hungary. The accommodation and catering industry, especially the sector of hotels represents the leading roles. Moreover, it is greatly promoted by different project resources, therefore the tourism service providers can more easily materialise an environmental friendly investment. There are only a few examples for developments financed by private capital. Both the social and environment responsibility are in their initial phase. Probably it is due to the slow spread of the formation of the attitude and the lack of the 'best practises'. Social responsibility is even weaker, which is mainly in connection with ensuring more pleasant and favourable working conditions for the staff.

To sum up, environmental and social sustainability require a comprehensive approach and intervention to the sector as a whole. Based on the research done, those stakeholders in hotel industry in Hungary who become or just make an effort to become responsible tourism service suppliers need to give advice to the others how to advance responsible approach and business practice. In our view, technical proposal could be shared on panel discussions or conventions managed and supervised by trade association or professional organisation, like Association of Hungarian Hotels and Restaurants.

\section{References}

Albert Tóth A. 2016. Fenntarthatóság és környezetvédelem a szállodaiparban. Területfejlesztés és Innováció 3, 16-29. (in Hungarian)

Dávid, L., Vargáné Csobán, K., Kovács, G., Vasa, L. 2012. Turizmusökológia: Zöldülő turizmusFenntartható turizmusfejlesztés, Szaktudás Kiadóház, Budapest, 233. (in Hungarian)

Goodwin, H. 2016. Industry and Consumer Views on Responsible Tourism In: Goodwin, H.-Font, X. (eds.): Progress in Responsible Tourism 5(1), Goodfellow Publishers Ltd. Oxford.

Gyurácz-Németh, P. 2014. A Magyar szállodák környezettudatos innovációi. Turizmus Bulletin XVI, 3-4, 68-75. (in Hungarian)

Kovács, B.D., Schmidt, F. 2015. Borwellness szolgáltatások megjelenése hazánk turisztikai kínálatában - A borwellness jó gyakorlata Villányban. In: Oroszi V. (ed.): Szőlő, bor, turizmus - Tanulmányok a szölészet, borászat és a borturizmus témaköréböl. PTE Kultúratudományi Pedagógusképző és Vidékfejlesztési Kar, Pécs, 126-14o. (in Hungarian)

Lanza, A., Markandya, A., Pigliaru, F. (ed.) 2005. The Economic of Tourism and Sustainable Development, Edward Elgar Publishing, Northamptom, 309.

Lengyel, M. 2004. A turizmus általános elmélete, Heller Farkas Gazdasági és Turisztikai Szolgáltatások Főiskolája, Budapest. (in Hungarian)

Michalkó, G. 2004. A turizmuselmélet alapjai, Kodolányi János Főiskola, Székesfehérvár. (in Hungarian) 
Michalkó, G. 2012. Turizmológia. Akadémiai Kiadó Zrt., Budapest, 203-214. (in Hungarian)

Page, S.J. 2007. Tourism Management: Managing for Change, Elsevier Ltd, Oxford, Second edition.

Petrić, L.2003. Osnove turizma, Ekonomski fakultet Split-X,124-146 (in Croatian)

Putzkó, L., Rátz, T. 2002. A turizmus hatásai, Aula Kiadó Kft., Budapest, 3. Átdolgozott kiadás, 461. (in Hungarian)

Ritchie, J.R.B., Crouch, G.I. 2003. The Competitive Destination- A Sustainable Tourism Perspective, CAB International Publishing, Cambridge, 267.

Swarbrooke, J. 1999. Sustainable Tourism Management. CAB International Publishing, Wallingford,UK, 13-14.

Swarbrooke, J., Horner, S. 2007. Consumer behaviour in Tourism, Elsevier Ltd., Oxford, Second edition, 177-21.

Tesone, D. 2015. Sustainability In: Principles of Management for the Hospitality Industry, Routledge, New York, 329-364.

\section{|| || ||}

Internet 1: 314/2005. (XII. 25.) Korm. Rendelet A környezeti hatásvizsgálati és az egységes környezethasználati engedélyezési eljárásról: https://net.jogtar.hu/jr/gen/hjegy_doc.cgi?docid=ao500314.kor\#lbj25oidfa68 (o2.08. 2017.)

Internet 2: AGENDA 21 for the Travel \& Tourism Industry Towards Environmentally Sustainable Development: https://wwwv1.agora21.org/johannesburg/rapports/omt-a21.html (12.07.2017)

Internet 3: Burgen, S.(update 01.08.2017): Barcelona anti-tourism activists vandalise bikes and bus: https://www.theguardian.com/world/2017/aug/o1/barcelona-anti-tourism-activists-vandalise-bikes-and-bus (03.08.2017.)

Internet 4: International Conference on Responsible Tourism in Destinations (2002) The Cape Town Declaration, Cape Town: http://responsibletourismpartnership.org/cape-town-declaration-on-responsible-tourism/ (14.08.2017.)

Internet 5: International Hotels Environment Initiative History: http://www.ihei.org/about-us/ history/ (10.07.2017.)

Magyar Szállodák és Éttermek Szövetsége: “Zöld Szálloda 2015-2016” pályázat nyertesei: http:// www.hah.hu/csr/zold-szalloda/zold-szalloda-palyazat-nyertesei/zold-szalloda-nyertesei-archiv/a-zold-szalloda-2015-2016-palyazat-nyertesei/ (10.07.2017.)

Internet 6: Magyar Szállodák és Éttermek Szövetsége: “Zöld Szálloda” pályázat nyertesei: http://www.hah.hu/csr/zold-szalloda/zold-szalloda-palyazat-nyertesei (10.07. 2017.)

Internet 7: UNWTO 2001: Global Code of Ethics for Tourism: http://ethics.unwto.org/sites/ all/files/docpdf/hungary_1.pdf (25.07.2017.)

Internet 8: WTTC 2017:Travel \& Tourism Economic impact 2017 Hungary: https://www.wttc. org/-/media/files/reports/economic-impact-research/countries-2017/hungary2017.pdf (20.08.2017) 